\title{
The Effect of Placement and Career Development on Employee Job Performance at PT Alam Abadi Sejahtera in Jakarta
}

\author{
Iman Syatoto \\ Universitas Pamulang \\ E-mail: imansyatoto@gmail.com
}

\begin{abstract}
Every company in carrying out its activities must have goals to be achieved. This study aims to determine the effect of placement and career development on employee work performance at PT. Alam Abadi Sejahtera in Jakarta. The method used was explanatory research with a sample of 95 respondents. The analysis technique uses statistical analysis with regression testing, correlation, determination and hypothesis testing. The results of this study the placement of a significant effect on employee performance by $40.9 \%$, hypothesis testing obtained significance $0,000<0.05$. Career development has a significant effect on employee performance by $42.2 \%$, hypothesis testing obtained significance 0,000 $<0.05$. Career placement and simultaneous simultaneous significant effect on employee performance by $51.6 \%$, hypothesis testing obtained significance $0,000<0.05$.
\end{abstract}

Keywords: Placement; career development; employee work performance

\section{INTRODUCTION}

Employee performance in general is an embodiment of work done by employees that is usually used as a basis or reference for assessing employees in an organization (Jamaluddin, Salam, Yunus, \& Akib, 2017; Sari, Jamaluddin, Saleh, \& Arhas, 2020; Sukmawati, Jamaluddin, Niswaty, \& Asmanurhidayani, 2019). Good performance is a step towards achieving organizational goals, therefore, performance is also a decisive means in achieving organizational goals so it needs to be sought to improve employee performance (Akib \& Saleh, 2015; Amirullah \& Darwis, 2015; Norani, Amirullah, \& Darwis , 2015).

Every company in carrying out its activities must have a goal to be achieved, to achieve or realize these goals, each company must be clever in choosing a strategy, especially human resource planning which is essentially focused on certain steps taken by management. The availability of permanent workers to occupy positions and the right time in order to achieve the objectives and various targets set. They view work as something noble so that the human resource factor in carrying out work must not be ignored. This can be seen from the smaller demand to pay attention to the human aspect rather than just focusing on the technological and economic aspects. Increasing competition in the world of work spurs companies to continue to improve performance, so as to achieve company goals that bring profit and benefit the community. To achieve company objectives electively, it is of course required high quality human resources (labor) and in accordance with the current field (Hasibuan, 2018, 2011; Marwansyah, 2010; Yani, 2011).

Companies in increasing productivity perform a form of activity that is the placement of workers or employees who have different levels of competence (Edison, Anwar, \& Komariyah, 


\section{Jurnal Administrare: Jurnal Pemikiran Ilmiah dan Pendidikan Administrasi Perkantoran Vol. 7, No. 1, January-June 2020, Pages 21-28}

2016; Gomes, 2003; Wirawan, 2015). This difference in ability is determined based on the results of recruitment (recruitment) and qualifications (qualifications) of the company. Even for the promotion of the position itself is determined based on the appointment of work itself. Job placement is one important factor that must not be ignored in achieving company goals. If the company puts the wrong employee in a place that is not their expertise, the employee's performance will not be maximal so that the company's goals are ineffective and inefficient. Employee performance and placement is very influential on the achievement of company goals. If the placement of employees is in accordance with their expertise, the employee's performance will be maximal so that the company's goals can be achieved (Abdullah, 2014; Kusuma \& Ardana, 2014; Reza, 2010; Tampi, 2014). In addition, in increasing the workforce (employees) there are other aspects for the achievement of company goals, namely career development of employees (career development). When employees do the same thing and repeatedly, it will have a bad impact, then the employee will experience burnout. To prevent this from happening, the employee career development process is definitely needed. According to (Hasibuan, 2011) career development is an attempt to improve the technical, theoretical, conceptual and moral abilities of employees in accordance with the needs of the job / position through education and training.

Job performance is as a result of work that has been achieved by a person from his work behavior in carrying out work activities in accordance with the standards desired by the company (Kammeyer-Mueller, 2015; Niswaty, AM, Saleh, Baharuddin, \& Arhas, 2019). Information about the level of work performance of an employee cannot be obtained just like that, but is obtained through a long process, namely the process of employee performance appraisal which is referred to as performance appraisal (De \& Pritchard, 2006; Toppo, 2012). Meanwhile, according to (Hasibuan, 2018) work performance is a result of work achieved by a person in carrying out tasks assigned to him based on skills, skills, experience, sincerity of time.

\section{METHOD}

The type of research used is associative, where the aim is to find out the connection between. The population in this study amounted to 95 respondents PT. Alam Abadi Sejahtera in Jakarta. The sampling technique in this study is saturated sampling, where all members of the population are sampled. Thus the sample in this study amounted to 95 respondents. In analyzing the data used the instrument test, classical assumption test, regression, coefficient of determination and hypothesis testing.

\section{RESULT AND DISCUSSION}

Job performance is the result of work obtained by employees in completing work based on input and output. The dimensions used include: work results, work knowledge, initiative, mental dexterity, and attitude

\section{Descriptive Analysis}

In this test used to determine the highest minimum and maximum scores, ratting scores and standard deviations of each variable. The results are as follows: 
Table 1

Statistical Descriptive Analysis Results

Descriptive Statistics

\begin{tabular}{lr|r|r|r|r}
\hline & N & Minimum & Maximum & $\begin{array}{c}\text { The } \\
\text { mean }\end{array}$ & Std. Deviation \\
\hline Placement (X1) & 95 & 32 & 48 & 38.48 & 3,862 \\
\hline Career Development (X2) & 95 & 30 & 45 & 38.43 & 3,706 \\
\hline Employee Performance (Y) & 95 & 32 & 46 & 39.15 & 3,576 \\
\hline Valid N (listwise) & 95 & & & & \\
\hline
\end{tabular}

Placement obtained a minimum variance of 32 and a maximum variance of 48 with a ratting score of 38.48 with a standard deviation of 3.862. Career development obtained a minimum variance of 30 and a maximum variance of 45 with a ratting score of 38.43 with a standard deviation of 3.706. Achievement of employees earned minimum variance of 32 and 46 with a maximum variance ratting score of 39.15 with a standard deviation of 3.576.

\section{Multiple Regression Analysis}

This regression test is intended to determine changes in the dependent variable if the independent variable changes. The test results are as follows:

\section{Table 2}

\section{Multiple Regression Testing Results}

\begin{tabular}{|c|c|c|c|c|c|c|}
\hline \multicolumn{7}{|c|}{ Coefficients $^{\text {a }}$} \\
\hline & \multirow[t]{2}{*}{ Model } & \multicolumn{2}{|c|}{$\begin{array}{c}\text { Unstandardized } \\
\text { Coefficients }\end{array}$} & \multirow{2}{*}{$\begin{array}{c}\text { Standardized } \\
\text { Coefficients } \\
\text { Beta }\end{array}$} & \multirow[t]{2}{*}{$\mathrm{t}$} & \multirow[t]{2}{*}{ Sig. } \\
\hline & & B & Std. Error & & & \\
\hline \multirow[t]{3}{*}{1} & (Constant) & 10,028 & 2,953 & & 3,396 & .001 \\
\hline & Placement (X1) & .359 & .085 & .388 & 4,234 & .000 \\
\hline & Career Development (X2) & .398 & .088 & .413 & 4,507 & .000 \\
\hline
\end{tabular}

a. Dependent Variable: Employee Job Performance (Y)

Based on the test results in the above table, the regression equation $\mathrm{Y}=10.028+$ $0.359 \mathrm{X} 1+0.398 \mathrm{X} 2$ is obtained . A constant of 10,028 means that if there is no placement and career development, then there is an employee performance value of 10,028 points. Placement regression coefficient of 0.359 , this number is positive, meaning that every time there is an increase in placement of 0.359 , employee work performance will also increase by 0.359 points. Career development regression coefficient of 0.398 , this number is positive meaning that every time there is an increase in career development of 0.398 , employee performance will also increase by 0,398 points. .

\section{Correlation Coefficient Analysis}

Correlation coefficient analysis is intended to determine the degree of relationship strength of the independent variables on the dependent variable either partially or simultaneously. The test results are as table 3 : 
24 Jurnal Administrare: Jurnal Pemikiran Ilmiah dan Pendidikan Administrasi Perkantoran Vol. 7, No. 1, January-June 2020, Pages 21-28

Table 3

Placement Correlation Coefficient Testing Results on Employee Job Performance. Correlations $^{\text {b }}$

\begin{tabular}{llr|r}
\hline & & $\begin{array}{c}\text { Placement } \\
(\mathrm{X} 1)\end{array}$ & $\begin{array}{c}\text { Employee } \\
\text { Performance (Y) }\end{array}$ \\
\hline Placement (X1) & Pearson Correlation & 1 & $.640^{* *}$ \\
\cline { 2 - 4 } Employee Performance (Y) & Sig. (2-tailed) & & .000 \\
\cline { 2 - 4 } & Pearson Correlation & $.640^{* *}$ & 1 \\
\cline { 2 - 4 } & Sig. (2-tailed) & .000 & \\
\hline
\end{tabular}

**. Correlation is significant at the 0.01 level (2-tailed).

b. Listwise $\mathrm{N}=95$

Based on the test results obtained a correlation value of 0.640 means that placement has a strong relationship with employee performance .

Table 4

Coefficient Test Results Correlation Career development towards Employee Job Performance

Correlations $^{b}$

\begin{tabular}{llr|r}
\hline & \multicolumn{1}{c}{ Correlations } & $\begin{array}{c}\text { Career } \\
\text { Development } \\
\text { (X2) }\end{array}$ & \multicolumn{1}{c}{$\begin{array}{c}\text { Employee } \\
\text { Performance (Y) }\end{array}$} \\
\hline Career Development (X2) & Pearson Correlation & 1 & $.649^{* * *}$ \\
\cline { 2 - 4 } & Sig. (2-tailed) & $.649^{* *}$ & .000 \\
\hline Employee Performance (Y) & Pearson Correlation & .000 & 1 \\
\cline { 2 - 4 } & Sig. (2-tailed) & & \\
\hline
\end{tabular}

**. Correlation is significant at the 0.01 level (2-tailed).

b. Listwise $\mathrm{N}=95$

Based on the test results obtained a correlation value of 0.649 means that career development has a strong relationship with employee performance.

Table 5

Correlation Coefficient Test Result Placement and Development Career Simultaneous $t$ erhadap Employee Job Performance

Summary Model

\begin{tabular}{|c|c|c|c|c|}
\hline Model & $\mathrm{R}$ & R Square & $\begin{array}{l}\text { Adjusted R } \\
\text { Square }\end{array}$ & $\begin{array}{l}\text { Std. Error of the } \\
\text { Estimate }\end{array}$ \\
\hline 1 & $.718^{\mathrm{a}}$ & .516 & .505 & 2,515 \\
\hline
\end{tabular}

a. Predictors: (Constant), Career Development (X2), Placement (X1)

Based on the test results obtained a correlation value of 0.718 means that simultaneous career placement and development has a strong relationship to employee work performance. 


\section{Analysis of the Coefficient of Determination}

Analysis of the coefficient of determination is intended to determine the percentage of influence of the independent variable on the dependent variable either partially or simultaneously. The test results are as follows:

Table 6

Coefficient Testing Results Efficient Determination of Placement on Employee Job Performance.

Summary Model

\begin{tabular}{lrr|rrr}
\hline Model & & & \multicolumn{2}{c}{$\begin{array}{c}\text { Adjusted } \mathrm{R} \\
\text { Square }\end{array}$} & \multicolumn{2}{c}{$\begin{array}{c}\text { Std. Error of the } \\
\text { Estimate }\end{array}$} \\
\hline 1 & $\mathrm{R}$ & R Square & .409 & .403 & 2,763 \\
\hline
\end{tabular}

a. Predictors: (Constant), Placement (X1)

Based on the test results obtained a determination value of 0.409 means that placement has an influence contribution of $40.9 \%$ on employee work performance.

Table 7.

Test Results for the Coefficient of Determination Career Development of Employee Job Performance.

\begin{tabular}{|c|c|c|c|c|}
\hline \multicolumn{5}{|c|}{ Model Summary } \\
\hline Model & $\mathrm{R}$ & R Square & $\begin{array}{l}\text { Adjusted R } \\
\text { Square }\end{array}$ & $\begin{array}{l}\text { Std. Error of the } \\
\text { Estimate }\end{array}$ \\
\hline 1 & $.649^{\mathrm{a}}$ & .422 & .415 & 2.734 \\
\hline
\end{tabular}

a. Predictors: (Constant), Career Development (X2)

Based on the test results obtained a determination value of 0.422 means that career development has an influence contribution of $42.2 \%$ on employee work performance .

\section{Table 8}

Test Results for Placement Determination Coefficient and Career Development on Employee Job Performance.

Model Summary

\begin{tabular}{lrr|rrr}
\hline Model & & \multicolumn{2}{c|}{$\begin{array}{c}\text { Adjusted R } \\
\text { Square }\end{array}$} & \multicolumn{2}{c}{$\begin{array}{c}\text { Std. Error of the } \\
\text { Estimate }\end{array}$} \\
\hline 1 & $\mathrm{R}$ & \multicolumn{2}{c|}{ R Square } & \multicolumn{2}{c}{ Squar } \\
\hline
\end{tabular}

a. Predictors: (Constant), Pengembangan Karir (X2), Penempatan (X1)

Based on the test results obtained a determination value of 0.516 means that simultaneous career placement and development has an influence contribution of $51.6 \%$ on Employee Work Performance, while the remaining 48.4 is influenced by other factors.

\section{Hypothesis testing}

Hypothesis testing with $\mathrm{t}$ test is used to find out which partial hypotheses are accepted. 
26 Jurnal Administrare: Jurnal Pemikiran Ilmiah dan Pendidikan Administrasi Perkantoran Vol. 7, No. 1, January-June 2020, Pages 21-28

Table 9

Placement Hypothesis Test Results on Employee Job Performance.

\section{Coefficients $^{\mathbf{a}}$}

\begin{tabular}{|c|c|c|c|c|c|c|}
\hline \multirow{2}{*}{\multicolumn{2}{|c|}{ Model }} & \multicolumn{2}{|c|}{$\begin{array}{l}\text { Unstandardized } \\
\text { Coefficients }\end{array}$} & \multirow{2}{*}{$\begin{array}{l}\text { Standardized } \\
\text { Coefficients } \\
\text { Beta }\end{array}$} & \multirow[b]{2}{*}{$\mathrm{t}$} & \multirow[b]{2}{*}{ Sig. } \\
\hline & & $\mathrm{B}$ & Std. Error & & & \\
\hline 1 & (Constant) & 16.354 & 2.855 & & 5.729 & .000 \\
\hline & Penempatan (X1) & .592 & .074 & .640 & 8.024 & .000 \\
\hline
\end{tabular}

a. Dependent Variable: Prestasi Kerja Karyawan (Y)

Based on the test results on the table above, the value of tcount $>t$ table or $(8.024>1.661)$ is obtained, thus the first hypothesis proposed that there is a significant influence on placement on Employee Job Performance is accepted.

Table 10

Hypothesis Test Results Career development towards Employee Job Performance.

\section{Coefficients ${ }^{\text {a }}$}

\begin{tabular}{|c|c|c|c|c|c|c|}
\hline \multirow{2}{*}{\multicolumn{2}{|c|}{ Model }} & \multicolumn{2}{|c|}{$\begin{array}{l}\text { Unstandardized } \\
\text { Coefficients }\end{array}$} & \multirow{2}{*}{$\begin{array}{c}\text { Standardized } \\
\text { Coefficients } \\
\text { Beta }\end{array}$} & \multirow[t]{2}{*}{$\mathrm{t}$} & \multirow[t]{2}{*}{ Sig. } \\
\hline & & B & Std. Error & & & \\
\hline \multirow[t]{2}{*}{1} & (Constant) & 15,071 & 2,937 & & 5,131 & .000 \\
\hline & Career Development (X2) & .626 & .076 & 649 & 8,234 & .000 \\
\hline
\end{tabular}

a. Dependent Variable: Employee Job Performance (Y)

Based on the test results in table 10 , the value of $t$ arithmetic $>t$ table or $(8.234>1.661)$, thus the second hypothesis proposed that there is a significant influence between career development on employee performance is accepted.

Hypothesis testing with the F test is used to find out which simultaneous hypotheses are accepted.

Table 11.

Hypothesis Placement Test Results and Career Development on Employee Job Performance.

ANOVA $^{\mathrm{a}}$

\begin{tabular}{llr|r|r|r|r} 
Model & Sum of Squares & df & Mean Square & F & \multicolumn{1}{c}{ Sig. } \\
\hline \multirow{2}{*}{1} & Regression & 620.171 & 2 & 310.086 & 49.037 & $.000^{\mathrm{b}}$ \\
\cline { 2 - 7 } & Residual & 581.766 & 92 & 6.324 & & \\
\cline { 2 - 7 } & Total & 1201.937 & 94 & & & \\
\hline
\end{tabular}

a. Dependent Variable: Employee Job Performance (Y)

b. Predictors: (Constant), Career Development (X2), Placement (X1) 
Based on the test results in the above table, the value of $F_{\text {count }}>F_{\text {table }}$ or $(49.037>2,700)$ is obtained, thus the third hypothesis proposed that there is a significant influence between placement and career development on Employee Work performance is accepted.

\section{CONCLUSION}

Based on the results of the study, the opportunity has a significant effect on employee performance while contributing 40.9\%. Hypothesis testing obtained $t$ count $>t$ table or (8.024> 1.661). Career development has a significant effect on employee performance while contributing $42.2 \%$. Hypothesis test obtained by value $t_{\text {count }}>t$ table or $(8.234>1.661)$. Placement and career development has a significant effect on Employee Job Performance with a contribution of $51.6 \%$ while the remaining 48.4 is influenced by other factors. Hypothesis testing obtained by the value of $F_{\text {count }}>F_{\text {table }}$ or $(49.037>2,700)$.

\section{REFERENCES}

Abdullah, M. M. (2014). Manajemen dan Evaluasi Kinerja Karyawan. In Perpustakaan Nasional RI.

Akib, H., \& Saleh, S. (2015). Pengaruh Kepala Sekolah Sebagai Supervisor Terhadap Kinerja Guru Di Smk Negeri 7 Makassar. Jurnal Office, 1(2), 141-147.

Amirullah, A. H., \& Darwis, M. (2015). Upaya Peningkatan Kinerja Pegawai pada Biro Administrasi Akademik dan Kemahasiswaan Universitas Negeri Makassar. Jurnal Office, 1(2), 180-184.

De, A. S., \& Pritchard, R. D. (2006). Performance Appraisal, Performance Management and Improving Individual Performance: A Motivational Framework. Management and Organization Review. https://doi.org/10.1111/j.1740-8784.2006.00042.x

Edison, E., Anwar, Y., \& Komariyah, I. (2016). Manajemen Sumber Daya Manusia. In Manajemen Sumber Daya Manusia.

Gomes, F. C. (2003). Manajemen sumber daya manusia. Yogyakarta: Andi.

Hasibuan. (2018). Manajemen Sumber Daya Manusia. In Manajemen Sumber Daya Manusia.

Hasibuan, M. S. P. (2011). Manajemen Sumber Daya Manusia. Edisi Revisi Jakarta: Bumi Aksara.

Jamaluddin, J., Salam, R., Yunus, H., \& Akib, H. (2017). Pengaruh budaya organisasi terhadap kinerja pegawai pada dinas pendidikan provinsi sulawesi selatan. Jurnal Ad'ministrare: Jurnal Pemikiran Ilmiah Dan Pendidikan Administrasi Perkantoran, 4(1), 25-34.

Kammeyer-Mueller, J. D. (2015). Human Resource Management Practices. In The Encyclopedia of Adulthood and Aging. https://doi.org/10.1002/9781118521373.wbeaa223

Kusuma, I., \& Ardana, K. (2014). Pengaruh Penempatan dan Kompensasi Terhadap Kepuasan Kerja dan Kinerja Karyawan. E-Jurnal Manajemen Universitas Udayana. 
28 | Jurnal Administrare: Jurnal Pemikiran Ilmiah dan Pendidikan Administrasi Perkantoran Vol. 7, No. 1, January-June 2020, Pages 21-28

Marwansyah. (2010). Manajemen Sumber Daya Manusia. Alfabeta: Jakarta. https://doi.org/10.1017/CBO9781107415324.004

Niswaty, R., AM, H. L., Saleh, S., Baharuddin, A., \& Arhas, S. H. (2019). The Implementation Effect of Industrial Work Practices on Student Work Readiness. Pinisi Business Administration Review, 1(1), 21-30.

Norani, M., Amirullah, A. H., \& Darwis, M. (2015). Efektivitas Kinerja Pegawai pada Kantor Kementerian Agama Kota Makassar. Jurnal Office, 1(1), 1-7.

Reza, R. A. (2010). Pengaruh Gaya Kepemimpinan, Motivasi dan Disiplin Kerja Terhadap Kinerja Karyawan PT Sinar Santosa Perkasa Banjarnegara. Pengaruh Gaya Kepimpinan, Motivasi Dan Disiplin Kerja Terhadap Kinerja Karyawan Pt Sinar Santosa Perkasa Banjarnegara.

Sanjaya, W. (2008). Kurikulum Dan Pembelajaran (Teori \& Praktek KTSP).

Sanjaya, W. (2010). Strategi Pembelajaran Berorientasi Standar Proses Pendidikan. System.

Sanjaya, W. (2015). Perencanaan dan Desain Sistem Pembelajaran. Kencana,Prenadamedia Group.

Sari, W. P. I., Jamaluddin, J., Saleh, S., \& Arhas, S. H. (2020). Influence of Compensation on Work Performance in the District Office of Bissappu, Bantaeng Regency. Jurnal Ad'ministrare, 6(2), 105-114.

Sukmawati, S., Jamaluddin, J., Niswaty, R., \& Asmanurhidayani, A. (2019). The Influence of Headmaster Leadership Style on Teacher Performance. Jurnal Office, 4(2), 91-102.

Tampi, B. J. (2014). Pengaruh Gaya Kepemimpinan dan Motivasi Terhadap Kinerja Karyawan Pada PT. Bank Negara Iindonesia, TBK (Regional Sales Manado). Jurnal 'Acta Diurna' Volume III. No.4.

Toppo, M. L. (2012). From Performance Appraisal to Performance Management. IOSR Journal of Business and Management. https://doi.org/10.9790/487x-0350106

Uno, H. H. B. (2010). Model pembelajaran: menciptakan proses belajar mengajar yang kreatif dan efektif. In Jakarta: Bumi Aksara. https://doi.org/10.1038/cddis.2011.1

Wirawan. (2015). Manajemen Sumber Daya Manusia Indonesia. In Depok.

Yani, M. (2011). Manajemen Sumber Daya Manusia. Jurnal Perspektif. https://doi.org/ISSN $1411-8637$ 